\title{
PENINGKATAN MINAT BACA DAN KEMAMPUAN MEMBACA PESERTA DIDIK KELAS RENDAH MELALUI PENGGUNAAN READING CORNER
}

\author{
INCREASING READING INTEREST AND ABILITY AT LOW CLASS STUDENT \\ USING READING CORNER
}

\author{
Ade Hendrayani \\ SD Negeri 7 Ciamis, Indonesia \\ hendrayani1507@gmail.com
}

\begin{abstract}
ABSTRAK
Latar belakang penelitian ini adalah realita masih memprihatikannya minat baca serta kemampuan membaca pada banyak peserta didik kelas rendah jenjang sekolah dasar. Reading Corner atau sudut baca adalah sebuah sudut di kelas yang dilengkapi dengan koleksi buku dan pajangan hasil karya peserta didik. Karakteristik pengelolaannya yang bersifat "dari, oleh dan untuk peserta didik", menyebabkan Reading Corner dapat dijadikan salah satu alternatif dalam meningkatkan meningkatkan minat baca serta kemampuan membaca mereka. Penelitian ini didasarkan pada rumusan masalah bagaimanakah penggunan reading corner untuk meningkatkan minat baca dan kemampuan membaca peserta didik kelas rendah serta apakah penggunan reading corner dapat meningkatkan minat baca dan kemampuan membaca peserta didik kelas rendah di SD Negeri 7 Ciamis? Metode penelitian yang digunakan adalah Penelitian Tindakan Kelas dengan dua siklus penelitian. Subjek penelitian adalah seluruh peserta didik kelas 3A SD Negeri 7 Ciamis tahun pelajaran 2016-2017 yang berjumlah 28 orang. Hasil penelitian menunjukkan bahwa penggunaan reading corner dapat meningkatkan minat baca peserta didik yang ditunjukkan dengan peningkatan indikator minat baca mereka, serta dapat meningkatkan kemampuan membaca yang ditunjukkan dengan peningkatan hasil tes kemampuan membaca mereka, mulai dari rata-rata 61,4 pada tes pra-PTK, menjadi 73,2 pada tes PTK siklus I dan menjadi 82,1 pada tes PTK siklus II.
\end{abstract}

Kata kunci: minat baca, kemampuan membaca, reading corner

\section{ABSTRACT}

The background of this study is the reality of less satisfactory of reading interest and reading ability on the low grade of of elementary school students. The reading corner is a space in the classroom that comes with a collection of books and displays of students' work. Characteristics of reading corner's management that is "from, by and for students", causing it can be used to increase their reading interest and their reading ability. This study is based on the formulation of the problem of how the use of reading corner to improve reading interest and reading ability of the low grade students and whether the use of reading corner can increase reading interest and reading ability of the low grade students in SD Negeri 7 Ciamis? The research method used is Classroom Action Research (CAR) with two research cycles. Research subjects are all students of class $3 A$ SD Negeri 7 Ciamis academic year 20162017 which amounted to 28 people. The results showed that the use of reading corner can improve reading ability which is indicated by the increase of their reading skill test result, from averaging 61.4 in the pre-CAR's test, then 73.2 and 82.1 in each CAR's test.

Keyword: reading interest, reading ability, reading corner

\section{PENDAHULUAN}

Bahasa Indonesia dalam kedudukannya sebagai bahasa nasional dan sebagai bahasa negara memegang peranan sangat strategis dan sentral bagi kelangsungan kehidupan bangsa dan negara Indonesia maupun bagi kehidupan warga negara secara individual, sehingga tuntutan untuk dapat menguasai bahasa Indonesia yang baik dan benar sejak dini bagi setiap warga negara Indonesia sudah merupakan satu keharusan yang tidak dapat ditawar lagi. Pembinaan dan pengembangan bahasa Indonesia melalui jalur pendidikan formal di sekolah merupakan jaluryang sangat efektif dan effisien. Sebagai pengejawantahan hal ini, dalam setiap kurikulum yang berlaku, mata pelajaran Bahasa Indonesia telah menjadi salah satu mata pelajaran yang wajib 
diberikan sejak jenjang sekolah dasar hingga jenjang sekolah menengah tingkat atas.

Pembelajaran bahasa Indonesia di sekolah secara umum ditujukan agar peserta didik mempunyai kompetensi dalam keempat aspek berbahasa yaitu mendengarkan/ menyimak, berbicara, membaca dan menulis. Keempat aspek berbahasa tersebut pada dasarnya merupakan satu kesatuan, merupakan catur tunggal (Tarigan, 2008). Tanpa mengesampingkan ketiga aspek lainnya, aspek berbahasa yang penting dan perlu mendapat perhatian lebih pada jenjang sekolah dasar khususnya pada kelas rendah (kelas 1,2, dan 3) adalah aspek membaca. Aspek membaca menjadi cukup penting pada kelas rendah jenjang sekolah dasar karena masih banyak peserta didik yang baru pertama kali belajar membaca (dan tentunya menulis) saat memasuki jenjang sekolah dasar, selain itu tidak dapat dipungkiri jika sebagian besar sumber belajar (bahan ajar) seluruh mata pelajaran di sekolah masih berupa media cetak yang hanya akan bisa dieksplorasi dengan baik jika peserta didik mempunyai kemampuan membaca yang baik.

Realita di lapangan berdasar hasil pengamatan penulis serta hasil diskusi dengan rekan sejawat khususnya yang mengajar di kelas rendah SD Negeri 7 Ciamis dapat diketahui bahwa kemampuan membaca peserta didik kelas rendah ternyata masih kurang memuaskan, masih cukup banyak peserta didik yang hingga kelas 3 (tingkat terakhir kelas rendah) membacanya masih belum lancar, selain itu kemampuan mereka dalam memahami bacaannya pun masih kurang memuaskan, seringkali mereka tidak dapat menangkap intisari wacana yang mereka baca dalam sekali membaca.
Hasil pengamatan penulis ini ternyata sangat relevan dengan hasil pengujian yang dilakukan oleh Asosiasi Internasional untuk Evaluasi Prestasi Pendidikan (IEA - the International Association for the Evaluation of Educational Achievement) dalam Progress in International Reading Literacy Study (PIRLS). Dalam PIRLS 2011 International Results in Reading, Indonesia menduduki peringkat ke-45 dari 48 negara peserta dengan skor 428 dari skor rata-rata 500 (IEA, 2012), yang menunjukkan bahwa kompetensi peserta didik Indonesia dalam memahami bacaan tergolong rendah.

Menurut analisa penulis, rendahnya kemampuan membaca peserta didik kelas rendah (khususnya di SD Negeri 7 Ciamis) disebabkan oleh masih terbatasnya metode pembelajaran membaca yang diterapkan serta masih miskinnya media pembelajaran yang digunakan dalam pembelajaran, pada umumnya guru masih masih menerapkan metode konvensional yang bersifat teacher centered, dimana proses belajar mengajar berpusat pada guru dengan penekanan pada peliputan dan penyebaran materi, sementara peserta didik cenderung kurang aktif sehingga mereka cepat merasa jenuh untuk mengikuti pembelajaran yang berujung pada kurang memuaskannya hasil belajar mereka. Selain itu menurut analisis penulis rendahnya kemampuan membaca pada peserta didik kelas rendah juga disebabkan oleh kurangnya minat baca mereka, hal ini ditunjukkan dengan masih rendahnya kunjungan peserta didik ke perpustakaan, pada saat senggang mereka lebih senang untuk bermain snartphone, game console, atau melakukan permainanpermainan lain dari pada membaca buku.

Upaya yang dapat dilakukan untuk mengatasi permasalahan berupa rendahnya 
kemampuan membaca peserta didik kelas rendahini dapat diupayakan denganmengubah metode pembelajaran dari yang bersifat teacher centered menjadi bersifat student centered, diharapkan peserta didik lebih banyak dilibatkan secara aktif dalam proses pembelajaran sebagaimana dikemukakan oleh (Kemp, 1977) bahwa "students are the center of the teaching dand learning process, so they have to be involved in almost all the phases of the classroom interaction from planning to evaluation". Untuk menuju pembelajaran yang bersifat student centered peran media pembelajaran akan sangat diperlukan sebagai jembatan interaksi antara peserta didik dengan peserta didik, peserta didik dengan guru dan peserta didik dengan sumber belajar, dan media pembelajaran yang layak dicoba sebagai alternatif dalam memenuhi tuntutan perubahan pembelajaran dari yang bersifat teacher centered menjadi bersifat student centered ini adalah reading corner (sudut baca).

Menurut Kamus Besar Bahasa Indonesia Edisi ke tiga (Bahasa, 2005), membaca didefinisikan sebagai melihat serta memahami isi dari apa yang tertulis dengan melisankan atau hanya dalam hati. Definisi ini tidak jauh berbeda dengan pendapat yang dikemukakan Finochiaro dan Bonomo dalam (Tarigan, 2008) yang secara singkat menyatakan bahwa "reading is bringing meaning to and getting meaning from printed or written material" (memetik serta memahami arti atau makna yang terkandung di dalam bahan tertulis), maupun pendapat yang dikemukakan oleh Anderson (dalam Alek dan Achmad, 2010:74) mengemukakan bahwa membaca ialah suatu proses untuk memahami yang tersirat dalam yang tersurat, melihat pikiran yang terkandung di dalam kata-kata yang tertulis. Dari berbagai pengertian membaca yang dikemukakan para ahli tersebut dapat disarikan bahwa membaca merupakan suatu keterampilan kompleks yang melibatkan keterampilan mekanis serta keterampilan pemahaman untuk memahami arti atau makna yang terkandung di dalam bahan tertulis.

Masih menurut Kamus Besar Bahasa Indonesia (Bahasa, 2005), minat didefinisikan sebagai kecenderungan hati yang tinggi terhadap sesuatu. Definisi ini hampir senada dengan pengertian minat yang dikemukakan oleh Muhibbin (Muhibbin, 2011) ,minat berarti kecenderungan dan kegairahan yang tinggi atau keinginan yang besar terhadap sesuatu, maupun pendapat Syaiful Bahri dalam (Djamarah, 2011) yang menyatakan bahwa minat adalah kecenderungan yang menetap untuk memperhatikan dan mengenang beberapa aktivitas, seseorang yang berminat terhadap suatu aktivitas akan memperhatikan aktivitas itu secara konsisten dengan rasa senang. Pendapat lain mengenai minat dikemukakan oleh (Hurlock, 1978) yang mendefinisikan minat sebagai sumber motivasi yang mendorong orang untuk melakukan apa yang mereka inginkan bila mereka bebas memilih. Pendapat ini hampir senada dengan pendapat (Slameto, 2013) menjelaskan bahwa minat adalah suatu rasa lebih suka dan rasa keterikatan pada suatu hal atau aktivitas, tanpa ada yang menyuruh. Jadi menurut kedua pendapat ini selain adanya kecenderungan untuk memperhatikan sesuatu, minat terjadi tanpa adanya suatu paksaan.

Berdasarkan pengertian minat maupun pengertian membaca yang telah dipaparkan, dapat disarikan bahwa minat membaca adalah kekuatan yang mendorong anak 
untuk memperhatikan, merasa tertarik dan senang terhadap aktivitas membaca sehingga mereka mau melakukan aktivitas membaca dengan kemauan sendiri. (Rahim, 2008) mengemukakan bahwa minat baca ialah keinginan yang kuat disertai usaha-usaha seseorang untuk membaca. Seseorang yang mempunyai minat membaca yang kuat akan berusaha mendapatkan bahan bacaan kemudian membacanya atas kesadaran sendiri maupun dorongan dari luar. Pendapat ni sesuai dengan pendapat Herman Wahadaniah (Yuliani, 2012) yang menyatakan bahwa minat baca adalah suatu perhatian yang kuat dan mendalam disertai dengan perasaan senang terhadap kegiatan membaca sehingga dapat mengarahkan seseorang untuk membaca dengan kemauannya sendiri atau dorongan dari luar.

Sementara itu kemampuan membaca dapat diartikan sebagai kesanggupan atau kemampuan untuk dapat memahami informasi yang ada dalam bacaan untuk mencapai tujuan dari kegiatan membaca. Memahami bacaan erat hubungannya dengan bagaimana menemukan informasi yang jelas diungkapkan (tersurat), dan informasi yang terungkap secara samar dan tidak langsung (tersirat) dari suatu teks bacaan. Pemahaman isi bacaan menjadi tujuan pokok dari pelajaran membaca dalam pengajaran bahasa, dan merupakan sasaran utama dari tes membaca. Kemampuan membaca itu ada kalanya perlu dipastikan tingkatnya melalui pengukuran dengan menyelenggarakan tes membaca. Tujuan tes membaca adalah untuk mengetahui dan mengukur tingkat kemampuan dalam memahami bahan bacaan. Soenardi Djiwandono (1996: 63) mengatakan bahwa kemampuan membaca tercermin dari tingkat pemahaman terhadap isi bacaan, baik yang secara jelas diungkapkan di dalamnya (tersurat), maupun yang hanya terungkap secara tidak langsung (tersirat) atau hanya sekedar implikasi dari isi bacaan. Kemampuan membaca seseorang tidaklah terbentuk begitu saja atau sudah dibawa sejak dilahirkan, namun diperoleh dan berkembang setahap demi setahap dengan dipengaruhi oleh berbagai faktor. Lamb dan Arnold dalam (Rahim, 2008) mengemukakan bebarapa faktor yang mempengaruhi kemampuan membaca yaitu:

a. Faktor fisiologis, yang mencangkup kesehatan fisik dan jenis kelamin;

b. Faktor intelektual;

c. Faktor Lingkungan, yang mencakup 1) latar belakang dan pengalaman peserta didik di rumah, dan 2) sosial ekonomi keluarga peserta didik.

d. Faktor Psikologis, mencakup 1) motivasi, 2) minat, 3) kematangan sosial, emosi, dan 4) penyesuaian diri.

Reading corner (sudut baca) adalah sebuah sudut di kelas yang dilengkapi dengan koleksi buku yang ditata secara menarik untuk menumbuhkan minat baca peserta didik, selain itu reading corner dapat digunakan untuk memajang koleksi bacaan dan karya peserta didik, berperan sebagai perpanjangan fungsi perpustakaan dan yang terpenting pengelolaannya dilakukan bersama oleh guru dan peserta didik dengan bantuan dari orang tua. Dengan adanya prinsip pengelolaan "dari, oleh dan untuk peserta didik", reading corner akan lebih meningkatkan partisipasi aktif peserta didik dalam proses pembelajaran dan yang juga cukup penting prinsip pengelolaan tersebut akan lebih meningkatkan minat baca peserta didik, karena buku-buku yang tersedia di reading corner merupakan buku-buku yang 
menjadi pilihan peserta didik sendiri.

Berangkat dari realita mengenai rendahnya minat baca dan kemampuan membaca peserta didik kelas rendah khususnya pada pembelajaran bahasa Indonesia, penelitian ini dilakukan dengan berdasar pada rumusan masalah bagaimanakah penggunaan reading corner untuk meningkatkan minat baca dan kemampuan membaca peserta didik kelas rendah serta apakah penggunan reading corner dapat meningkatkan minat baca dan kemampuan membaca peserta didik kelas rendah di SD Negeri 7 Ciamis?

\section{METODE PENELITIAN}

Mengingat tujuan utama penelitian yang dilaksanakan adalah perbaikan pembelajaran (kemampuan membaca), maka jenis penelitian yang paling cocok digunakan adalah Penelitian Tindakan Kelas (PTK). Jenis PTK yang dilaksanakan adalah kolaboratif antara peneliti sebagai inovator pembelajaran dengan guru mitra yang bertindak sebagai guru kelas pelaksana pembelajaran. Model PTK yang digunakan adalah adaptasi dari Model Kemmis dan Mc. Taggart yang dikembangkan Kasbolah (1998/1999: 70). Tindakan yang akan dilaksanakan merupakan suatu proses berbentuk spiral, setiap siklus tindakan penelitian identik dengan dua pertemuan pembelajaran yang masing-masing terdiri atas: tahap perencanaan; tahap pelaksanaan; tahap observasi, dan tahap refleksi.

Secara diagramatis model penelitian tindakan kelas (gambar 1) yang akan dilaksanakan dapat digambarkan sebagai berikut:

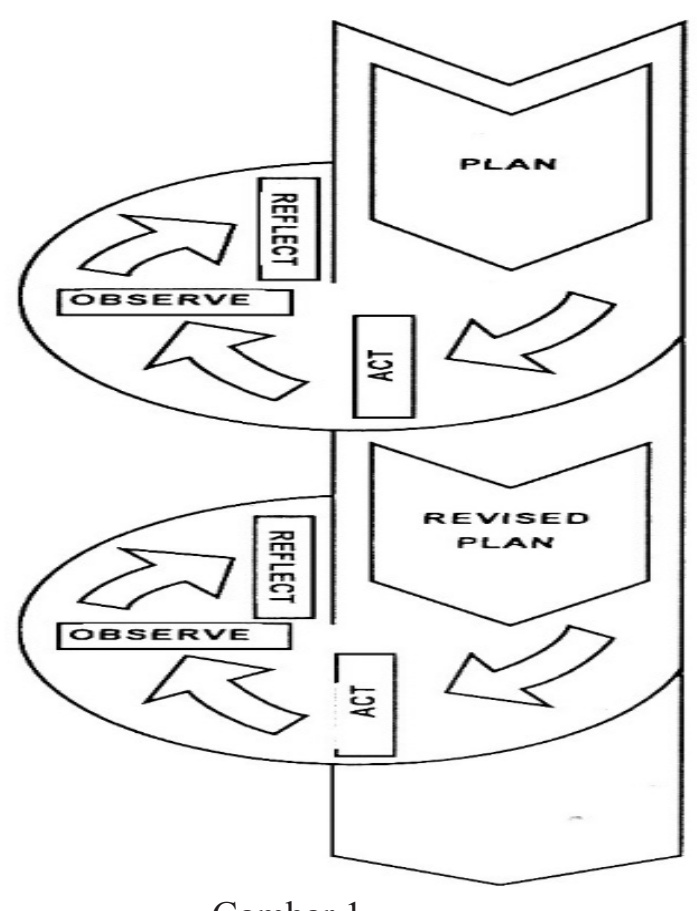

Gambar 1

Alur Pelaksanaan Tindakan dalam Penelitian Tindakan Kelas

Waktu pelaksanaan penelitian disesuaikan dengan alokasi yang telah direncanakan untuk pembelajaran bahasa Indonesia Kelas 3 Sekolah Dasar dengan Kompetensi Dasar 7.1. Menjawab dan atau mengajukan pertanyaan tentang isi teks agak panjang (150 - 200 kata) yang dibaca secara intensif. Penelitian dilaksanakan dalam dua siklus penelitian, tiap siklus terdiri dari dua pertemuan yang masing-masing berdurasi 35 menit. 
a. Penelitian Tindakan Kelas Siklus I

- Pertemuan pertama pada hari Selasa tanggal 17 Januari 201.

- Pertemuan kedua pada hari Kamis tanggal 19 Januari 2017.

b. Penelitian Tindakan Kelas Siklus II

- Pertemuan pertama pada hari Selasa tanggal 7 Pebruari 2017.

- Pertemuan kedua pada hari Kamis tanggal 9 Pebuari 2017.

Subjek penelitian adalah seluruh peserta didik kelas 3A SD Negeri 7 Ciamis tahun pelajaran 2016-2017 yang berjumlah 28 orang, terdiri dari 14 orang laki-laki dan 14 orang perempuan.

Sesuai model Penelitian Tindakan Kelas yang dipilih, secara garis besar prosedur penelitian yang dilaksanakan adalah sebagai berikut:

a. Tahap Perencanaan

Pada tahap ini peneliti melakukan kegiatan-kegiatan yang meliputi: 1) penyusunan rencana tindakan dalam bentuk RPP (Rencana Pelaksanaan Pembelajaran) untuk kompetensi dasar terkait; 2) bersama guru mempersiapkan fasilitas dan sarana pendukung yang diperlukan dalam pembelajaran (termasuk mempersiapkan Reading Corner dengan koleksi terkait materi pembelajarn yang akan disampaikan);

3) mempersiapkan instrumen penelitian yang akan digunakan, peneliti membangun kesepahaman dengan guru mengenai aspek-aspek penelitian.

b. Tahap Pelaksanaan

Tahap pelaksanaan penelitian adalah pelaksanaan tindakan penelitian sesuai skenario tindakan yang telah disusun dalam bentuk RPP oleh guru. Secara garis besar tindakan-tindakan yang dilaskanakan dalam setiap siklusnya adalah sebagai berikut:

Pertemuan pertama Siklus I, pertemuan diawali dengan pengkondisian peserta didik melalui presensi, pemberian motivasi dan pemberian apersepsi dilanjutkan dengan penyampaian tujuan, indikator serta metode pembelajaran yang akan digunakan. Tes awal dilakukan untuk mengetahui kemampuan awal peserta didik sebelum mengikuti pembelajaran yang merupakan penelitian tindakan. Inti pembelajaran diawali penjelasan guru mengenai cara membaca intensif, membuat pertanyaan dari bacaan serta menjawab pertanyaan berdasarkan hasil bacaan dilanjuutkan dengan pembagian Lembar Kerja berisi pedoman eksplorasi pembelajaran dan mempersilahkan peserta didik menuju reading corner untuk mengeksplorasi pembelajaran sesuai Lembar Kerja yang diberikan. Sebagai bagian akhir pembelajaran, guru membuka forum tanya jawab untuk mengakomodasi kesulitan atau permasalahan selama pembelajaran serta membimbing peserta didik untuk menyimpulkan hasil pembelajaran.

Pertemuan kedua Siklus I, secara garis besar skenario pembelajarannya sama dengan skenario pembelajaran pada pertemuan pertama siklus I hanya tidak dilakukan tes awal, dan pembelajaran diakhiri dengan tes akhir siklus.

Pertemuan pertama Siklus II, secara garis besar skenario pembelajarannya masih sama dengan skenario pembelajaran pada pertemuan pertama siklus I tanpa pelaksanaan tes awal.

Pertemuan kedua siklus II, secara garis besar skenario pembelajarannya sama 
dengan skenario pembelajaran pada pertemuan kedua siklus I.

c. Tahap Observasi

Pada tahap ini peneliti dan guru mengamati berbagai aspek penelitian tindakan baik menyangkut prosedur penelitian maupun respon yang diberikan peserta didik terhadap tindakan yang diberikan.

d. Tahap Analisis dan Refleksi

Pada tahap ini peneliti dan guru menganalisis hasil observasi dan merefleksilkannya sebagai bahan untuk penelitian tindakan siklus berikutnya atau pengambilan kesimpulan penelitian.

Teknik dan instrumen yang digunakan dalam pengumpulan data selama pelaksanaan penelitian tindakan kelas ini adalah:

a. Teknik Angket

Teknik angket digunakan untuk mengetahui minat baca peserta didik sebelum serta sesudah pelaksanaan penelitian tindakan. Instrumen yang digunakan adalah angket yang berisi pertanyaan terstruktur dan tidak tersetruktur dengan jumlah pertanyaan sebanyak lima butir pertanyaan. Penyebaran angket dilakukan dua kali, pertama pada tanggal 10 Januari 2017 dan yang kedua pada tanggal 18 Pebruari 2017.

\section{b. Teknik Observasi}

Teknik observasi digunakan untuk mengamati berbagai aspek penelitian tindakan baik menyangkut prosedur penelitian maupun respon yang diberikan peserta didik terhadap tindakan yang diberikan. Instrumen yang digunakan adalah jurnal penelitian/ catatan lapangan untuk mencatat semua kegiatan yang diobservasi dan kamera untuk merekam semua pelaksanaan PTK secara audio visual.

c. Teknik Tes

Teknik Tes digunakan untuk menilai peningkatan kemampuan membaca peserta didik selama melakukan penelitian tindakan. Instrumen yang digunakan berupa wacana berupa cerita dengan panjang 150 - 200 kata yang dilengkapi pertanyaan berbentuk jawaban singkat.

Adapun Teknik analisis data yang digunakan untuk menganilis data-data yang diperoleh selama penelitian meliputi:

a. Analisis Kualitatif

Teknik analisis kualitatif digunakan untuk menganalisis hasil angket serta hasil observasi terhadap prosedur pelaksanaan penelitian serta respons peserta didik selama melaksanakan penelitian tindakan

b. Analisis Kuantitatif

Analisis kuantitatif digunakan untuk menganalisis data hasil tes yang diperoleh selama penelitian. Secara garis besar prosedur analisis yang dilaksanakan terhadap setiap hasil tes adalah sebagai berikut:

- Merekap skor serta nilai hasil tes masing-masing peserta didik dengan rumus sederhana:

$$
\text { Nilai }=\frac{\text { skor }}{\text { skor maksimal }} \times 100
$$

- Membuat tabel distribusi nilai tes peserta didik.

- Menghitung nilai rata-rata kelas dengan menggunakan rumus:

$$
\text { Rerata }=\frac{\text { jumlah nilai peserta didik }}{\text { jumlah peserta didik }}
$$

- Menentukanjumlah peserta didik yang memenuhi KKM dan menentukan persentasenya dengan rumus: 


$$
P(\%)=\frac{\text { jumlah yang lulus } K K M}{\text { jumlah peserta didik }} \times 100 \%
$$

Hasil analisis diinterpretasikan sebagai peningkatan kemampuan membaca peserta didik selama mengikuti penelitian tindakan kelas.

Indikator keberhasilan penelitian tindakan kelas yang dilaksanakan adalah jika terjadi peningkatan pada minat baca peserta didik serta paling tidak $75 \%$ peserta didik dapat memenuhi Kriteria Ketuntasan Minimum (KKM) mata pelajaran bahasa Indonesia Kelas 3 di SD Negeri 7 Ciamis untuk Kompetensi Dasar 7.1. Menjawab dan atau mengajukan pertanyaan tentang isi teks agak panjang (150 - 200 kata) yang dibaca secara intensif, yang ditentukan sebesar 76 .

\section{HASIL PENELITIAN}

Berdasar observasi selama pelaksanaan penelitian tindakan kelas yang dilaksanakan dalam empat pertemuan pembelajaran dapat diamati bahwa implementasi penggunaan reading corner pada pembelajaran bahasa Indonesia ternyata mendapat respons yang sangat baik dari peserta didik. Hamper seluruh peserta didik nampak lebih nyaman melakukan kegiatan membaca intensif direading corner daripada dibangku masingmasing seperti biasanya, apalagi wacana yang harus dibaca dapat mereka pilih sendiri dengan topik sesuai kegemarannya masingmasing. Dari segi guru tidak ada kesulitan sedikit pun untuk mengimplementasikan penggunaan reading corner dalam pembelajaran membaca intensif mata pelajaran bahasa Indonesia, masalah hanya terjadi saat guru harus menyediakan bahan bacaan yang sesuai dengan materi pelajaran, namun dapat diatasi melalui kerjasama dengan pengelola perpustakaan sekolah untuk mempersiapkan buku-buku tersebut.

Hasil analisis angket minat baca yang disebar sebelum dan sesudah pelaksanaan penelitian tinakan kelas dapat dilihat dari tabel-tabel berikut:

Tabel 1

Rekapitulasi jawaban angket No. 1

\begin{tabular}{lcc}
\hline \multirow{2}{*}{ Jawaban } & \multicolumn{2}{c}{ Frekuensi Jawaban } \\
\cline { 2 - 3 } & Sebelum & Sesudah \\
\hline Ya & 10 & 21 \\
\hline Tidak & 18 & 7 \\
\hline
\end{tabular}

Rekapitulasi jawaban untuk angket No.1 pada tabel 1 (Apakah kamu suka membaca?), menunjukkan adanya peningkatan yang sangat mencolok antara sebelum adanya penggunaan Reading Corner dengan setelah adanya penggunan Reading Corner, jiak sebelum ada penggunaan Reading Corner hanya 10 orang atau $35,7 \%$ yang suka membaca maka setelah ada penggunaan Reading Corner 21 orang peserta didik atau $75 \%$ peserta didik menyatakan suka membaca atau mengalami kenaikan $110 \%$.

Tabel 2

Rekapitulasi jawaban angket No. 2

\begin{tabular}{lcc}
\hline \multirow{2}{*}{ Jawaban } & \multicolumn{2}{c}{ Frekuensi Jawaban } \\
\cline { 2 - 3 } & Sebelum & Sesudah \\
\hline 0 & 10 & 0 \\
\hline $1-3$ & 15 & 19 \\
\hline Diatas 3 & 3 & 9 \\
\hline
\end{tabular}


Rekapitulasi jawaban untuk angket No.2 pada tabel 2 (Berapa judul buku yang telah kamu baca dalam satu bulan terakhir?), menunjukkan selain telah terjadi jumlah peserta didik yang suka membaca, jumlah buku yang mereka baca pun mengalami peningkatan, jika sebelum ada 10 peserta didik yang sama sekali belum menyelesaikan membaca satu judul buku pun dan hanya

Tabel 3

Rekapitulasi jawaban angket No. 3

\begin{tabular}{lcc}
\hline \multirow{2}{*}{ Jawaban } & \multicolumn{2}{c}{ Frekuensi Jawaban } \\
\cline { 2 - 3 } & Sebelum & Sesudah \\
\hline Diri sendiri & 3 & 13 \\
\hline Keluarga & 5 & 5 \\
\hline Teman & 5 & 5 \\
\hline Guru & 15 & 10 \\
\hline
\end{tabular}

Rekapitulasi jawaban untuk angket No.3 pada tabel 3 (Siapa yang memotivasi untuk lebih giat membaca?), menunjukkan adanya pergeseran siapa yang memotivasi untuk lebih giat membaca, jika sebelum ada Reading Corner guru menempati peringkat pertama dengan 15 peserta didik atau 53,6\%
3 peserta didik yang telah menyelesaikan membaca diatas 3 buah judul buku, maka setelah ada penggunaan Reading Corner semua peserta didik telah berhasil menyelesaikan membaca buku dan jumlah peserta didik yang berhasil membaca diatas 3 buah judul buku telah mencapai 9 orang atau meningkat $200 \%$.

\section{Tabel 4}

Rekapitulasi jawaban angket No. 4

\begin{tabular}{lcc}
\hline \multirow{2}{*}{ Jawaban } & \multicolumn{2}{c}{ Frekuensi Jawaban } \\
\cline { 2 - 3 } & Sebelum & Sesudah \\
\hline Buku sastra/fiksi & 0 & 4 \\
\hline Koran/ majalah & 5 & 4 \\
\hline Buku pelajaran & 18 & 12 \\
\hline Buku pengetahuan & 5 & 8 \\
\hline
\end{tabular}

Rekapitulasi jawaban untuk angket No.4 pada tabel 4 (Buku apa yang biasa kamu baca?), menunjukkan semakin beragamnya buku yang dibaca oleh peserta didik, jika sebelum ada Reading Corner mayoritas yang dibaca peserta didik adalah buku pelajaran yang dibaca oleh 18 peserta didik atau 64,3\% dan hanya 5 peserta didik yang masingmasing membaca buku pengetahuan dan majalah/koran, maka setelah ada Reading Corner buku yang dibaca menjadi lebih beragam dengan sebaran masing-masing $14,3 \%$ peserta didik yang membaca buku sastra/fiksi serta majalah/koran, 42,9\% peserta didik membaca buku pelajaran dan $28,5 \%$ peserta didik yang membaca buku pengetahuan. 
Tabel 5

Rekapitulasi jawaban angket No. 5

\begin{tabular}{lcc}
\hline \multirow{2}{*}{ Jawaban } & \multicolumn{2}{c}{ Frekuensi Jawaban } \\
\cline { 2 - 3 } & Sebelum & Sesudah \\
\hline Di rumah & 16 & 5 \\
\hline Di kelas & 4 & 21 \\
\hline Di perpustakaan & 8 & 2 \\
\hline Di tempat terbuka & 0 & 0 \\
\hline
\end{tabular}

Rekapitulasi jawaban untuk angket No.5 pada tabel 5 (Dimana kamu paling sering membaca?), juga mengalami perubahan, jika sebelum ada Reading Corner mayoritas peserta didik membaca di rumah yang dilakukan oleh 16 peserta didik atau 57\%, maka setelah ada Reading Corner 21 peserta didik atau $75 \%$ menjadikan kelas sebagai tempat membaca.

Sementara itu rekapitulasi hasil tes awal, tes akhir PTK siklus I, dan tes akhir PTK siklus II dapat dilihat pada tabel 6 berikut:

Tabel 6

Rekapitulasi Hasil Tes Selama Pelaksanaan PTK

\begin{tabular}{lccccc}
\hline \multirow{2}{*}{ No. } & \multirow{2}{*}{ Kode Peserta Didik } & \multicolumn{3}{c}{ Nilai Hasil Tes } & \multirow{2}{*}{ Nilai KKM } \\
\cline { 2 - 5 } 1 & S-1 & 80 & 100 & 100 & 76 \\
\hline 2 & S-2 & 60 & 80 & 90 & 76 \\
\hline 3 & S-3 & 60 & 70 & 80 & 76 \\
\hline 4 & S-4 & 50 & 50 & 70 & 76 \\
\hline 5 & S-5 & 60 & 80 & 80 & 76 \\
\hline 6 & S-6 & 60 & 70 & 80 & 76 \\
\hline 7 & S-7 & 50 & 50 & 70 & 76 \\
\hline 8 & S-8 & 80 & 90 & 90 & 76 \\
\hline 9 & S-9 & 60 & 60 & 90 & 76 \\
\hline 10 & S-10 & 50 & 70 & 80 & 76 \\
\hline 11 & S-11 & 60 & 70 & 80 & 76 \\
\hline 12 & S-12 & 60 & 80 & 90 & 76 \\
\hline 13 & S-13 & 50 & 70 & 90 & 76 \\
\hline 14 & S-14 & 70 & 100 & 100 & 76 \\
\hline 15 & S-15 & 60 & 60 & 70 & 76 \\
\hline 16 & S-16 & 80 & 90 & 90 & 76 \\
\hline 17 & S-17 & 60 & 80 & 80 & 76 \\
\hline 18 & S-18 & 60 & 70 & 70 & 76 \\
\hline 19 & S-19 & 60 & 70 & 80 & 76 \\
\hline 20 & S-20 & 80 & 80 & 80 & 76 \\
\hline 21 & S-21 & 50 & 70 & 80 & 76 \\
\hline 22 & S-22 & 70 & 80 & 80 & 76 \\
\hline 23 & S-23 & 50 & 50 & 60 & 76 \\
\hline 24 & S-24 & 70 & 90 & 100 & 76 \\
\hline 25 & S-25 & 50 & 60 & 70 & 76 \\
\hline 26 & S-26 & 60 & 60 & 80 & 76 \\
\hline 27 & S-27 & 60 & 80 & 90 & 76 \\
\hline 28 & S-28 & 60 & 70 & 80 & 76 \\
\hline & Rata-rata & 61,4 & 73,2 & 82.1 & 76 \\
\hline & & & & & \\
\hline
\end{tabular}


Hasil analisis lebih lanjut berupa sebaran frekuensi nilai hasil tes awal, tes akhir PTK siklus I, dan tes akhir PTK siklus II dapat dilihat pada gambar 2 berikut:

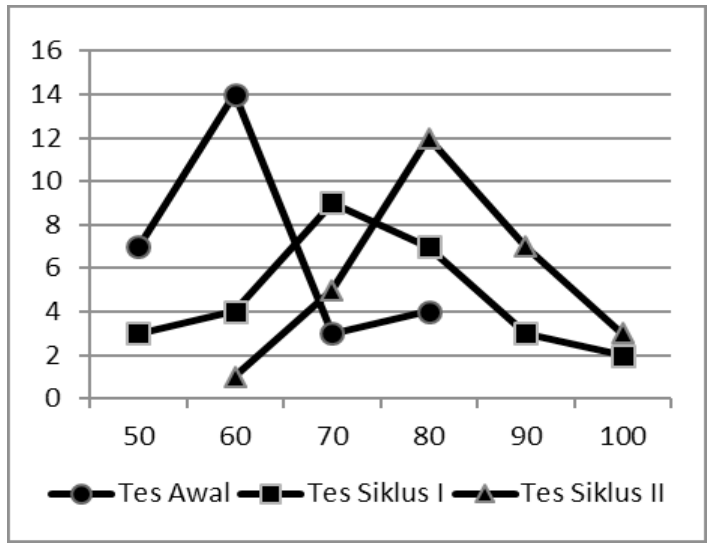

Gambar 2. Sebaran Nilai Hasil Tes Selama Pelaksanaan PTK

\section{PEMBAHASAN}

Reading Corner (sudut baca) adalah sebuah sudut di ruangan kelas yang dilengkapi dengan koleksi buku yang ditata secara menarik untuk menumbuhkan minat baca peserta didik, selain itu reading corner dapat digunakan untuk memajang koleksi bacaan dan karya peserta didik. Reading corner berperan sebagai perpanjangan fungsi perpustakaan sekolah yaitu mendekatkan buku kepada peserta didik, namun reading corner tidak sama dengan perpustakaan karena reading corner mempunyai karakteristik khusus yaitu: (NCERT, 2008:3)

a. Reading Corner adalah "milik" peserta didik dan merupakan bagian dari ruangan kelas mereka dimana buku-buku dengan mudah dapat mereka akses.

b. Peserta didik mempunyai kebebasan untuk memilih buku-buku untuk mereka sendiri dan membaca berbagai macam buku yang ditampilkan secara menarik.

c. Memberi kebebasan kepada peserta didik untuk membaca mandiri maupun bergabung dalam kegiatan membaca secara berkelompok.

d. Reading Corner adalah tanggung jawab bersama antara peserta didik dan guru untuk menyedikan, menggunakan dan memelihara buku-buku yang ada di reading corner.

e. Reading Corner merupakan bagian integral dari pelaksanan aktivitas pembelajaran.

Hasil analisis terhadap angket minat baca yang disebar sebelum dan setelah pelaksanaan penelitian tindakan kelas dengan indikator yang disusun sesuai dengan pendapat (Dalman, 2014) yang mengemukakan bahwa indikator minat baca dapat menggunakan: (1) frekuensi dan kuantitas membaca; (2) kuantitas bahan bacaan, serta pendapat Bastiano (2010: 427) yang mengemukakan empat indikatorminat baca yaitu: (1) kesenangan membaca; (2) kesadaran akan manfaat membaca; (3) frekuensi membaca; dan (3) jumlah buku yang pernah dibaca, diperoleh hasil bahwa pelaksanaan penelitian tindakan kelas berupa penggunaan Reading Corner dalam pembelajaran membaca pada pelajaran bahasa Indonesia telah berhasil meningkatkan minat baca peserta didik yang secara nyata ditunjukkan oleh semakin tingginya peserta didik yang merasa senang membaca, semakin tingginya kuantitas (jumlah) buku yang mereka baca, semakin beragamnya buku yang mereka baca dan yang terjelas adalah semakin seringnya mereka berada di Reading Corner untuk membaca koleksi-koleksi Reading Corner mereka. Selain itu bergesernya motivator membaca dari guru kepada peserta didik menunjukkan semakin tingginya kesadaran peserta didik untuk membaca atas keinginan sendiri.

Peningkatan minat baca peserta didik 
selama mengikuti penelitian tindakan sangat sesuai dengan yang telah diperkirakan sebelumnya. Menurut Bunata (Dalman, 2014) minat baca ditentukan oleh beberapa faktor, yaitu: faktor lingkungan keluarga, faktor kurikulum dan pendidikan sekolah, faktor infrastruktur masyarakat, dan faktor keberadaan dan kejangkauan bahan bacaan. Penggunaan reading corner dalam pembelajaran membaca selama pelaksanaan penelitian tindakan secara langsung telah mendekatkan keberadaan dan kejangkauan bahan bacaan selain "sedikit merubah "kurikulum dan pendidikan sekolah".

Peningkatan kemampuan membaca peserta didik subjek penelitian yang terjadi selama pelaksanaan penelitian tindakan kelas merupakan dampak langsung dari lebih banyaknya keterlibatan aktif peserta didik dalam pembelajaran, mereka terlibat aktif dalam pemilihan materi bacaan yang harus dibaca secara intensif, mereka juga terlibat secara aktif untuk memilih tempat yang menurut mereka nyaman untuk membaca. Selain itu peningkatan kemampuan membaca peserta didik yang terjadi merupakan konsekuensi dari meningkatnya minat baca mereka setelah menggunakan Reading Corner. Eratnya hubungan antara peningkatan minat baca dengan peningakatan kemampuan membaca ini telah dikemukakan oleh para ahli diantaranya Buron dan Claybaung dalam (Somadayo, 2011) menyatakan bahwa tingkat pencapaian kemampuan membaca pemahaman seseorang sangat dipengaruhi oleh hal yang disebut kesiapan membaca. Kesiapan membaca tersebut berwujud intelegensi, kematangan emosi dan minat, pengalaman, kepemilikan fasilitas bahasa lisan, dan sikap dan minat, selain itu (Rahim, 2008) menyatakan bahwa orang yang mempunyai minat membaca yang kuat akan diwujudkannya dalam kesediaanya untuk mendapat bahan bacaan dan kemudian membacanya atas kesadarannya sendiri. Minat baca selalu berkaitan dengan perasaan senang dan adanya perhatian terhadap kegiatan membaca.

\section{SIMPULAN}

Peningkatan nilai hasil tes yang terus terjadi secara berkesinambungan selama penelitian tindakan kelas (test awal, tes akhir PTK Siklus I dan tes akhir PTK siklus II) menunjukkan bahwa penelitian tindakan kelas yang dilaksanakan telah berhasil meningkatkan kemampuan membaca peserta didik kelas 3A (kelas rendah) SD Negeri 7 Ciamis, sementara itu peningkatan jumlah peserta didik yang lulus KKM menunjukkan bahwa penelitian tindakan kelas yang dilaksanakan dapat diterima dengan baik oleh seluruh peserta didik tidak terbatas pada peserta didik dengan kemampuan tertentu saja.

\section{REKOMENDASI}

Sebagai tindak lanjut dari hasil penelitian yang telah dicapai, dengan ini peneliti memberikan beberapa rekomendasi sehubungan dengan implementasi penggunaan Reading corner dalam pembelajaran:

Pertama, bagi rekan-rekan sejawat (guru/ tenaga pendidik) kiranya dapat mencoba membuat Reading Corner di kelasnya masing-masing untuk meningkatkan minat baca peserta didik sebagai implementasi Gerakan Literasi Sekolah sebagaimana diamanatkan Peraturan Menteri Pendidikan dan Kebudayaan Nomor 23 Tahun 2015 dengan salah satu kegiatan di dalam gerakan tersebut adalah "kegiatan 15 menit membaca buku non pelajaran sebelum waktu belajar 
dimulai".

Kedua, bagi guru kelas rendah jenjang sekolah dasar yang mengalami masalah berupa rendahnya minat baca serta kemampuan membaca peserta didiknya dapat mencoba membuat reading corner dan mengimplementasikannya dalam pembelajaran membaca untuk meningkatkan minat baca serta meningkatkan kemampuan membaca peserta didiknya.
Ketiga, menghimbau rekan sejawat (guru/ tenaga pendidik) yang telah mempunyai Reading Corner untuk mencoba mengimplementasikan penggunaannya dalam pembelajaran dalam upaya memperluas akses mereka kepada bahan-bahan pelajaran yang umumnya berupa media cetak dengan harapan dapat meningkatkan minat baca mereka yang akhirnya dapat berujung kepada peningkatan hasil belajar mereka.

\section{DAFTAR RUJUKAN}

Bahasa, T. P. K. P. (2005). Kamus Besar Bahasa Indonesia. Jakarta: Balai Pustaka.

Dalman. (2014). Keterampilan Membaca. Jakarta: Rajawali Pers.

Djamarah, S. B. (2011). Psikologi Belajar. Jakarta: Rineka Cipta.

Hurlock, E. B. (1978). Perkembangan Anak. Jakarta: Erlangga.

Kemp, J. E. (1977). Instructional Design Belmont, California: David S. Lake Publishers. NCERT, (2008). Reading Corner. New Delhi: Department of Elementary Education.

Muhibbin, S. (2011). Psikologi Pendidikan. Bandung: PT. Remaja Rosdakarya.

Rahim, F. (2008). Pengajaran Membaca di Sekolah Dasar (2nd ed.). Jakarta: Bumi Aksara.

Slameto. (2013). Belajar dan Faktor-faktor yang Mempengaruhinya. Jakarta: Rineka Cipta.

Somadayo, S. (2011). Strategi dan Teknik Pembelajaran Membaca. Yogyakarta: Graha Ilmu.

Tarigan, H. G. (2008). Membaca Sebagai Suatu Keterampilan Berbahasa. Bandung: Angkasa.

Yuliani, I. (2012). Hubungan Minat Baca Buku IPS dengan Prestasi Belajar IPS Siswa Kelas V SD Se-Gugus 3 Kecamatan Pleret Kabupaten Bantul Yogyakarta Tahun Ajaran 2011/2012. UNY. 